\title{
EXISTENCE OF LISTERIA SPECIES IN FRESHWATER FISH AND ITS CONTROL USING SANITIZED ICE
}

\author{
M.A.M. AMMAR*; GHADA M. MOHAMED* and NAHED M. ABD ELAZIZ** \\ * Animal Health Research Institute, Assiut Regional Lab. \\ ${ }^{* *}$ Fac. Vet. Med. Sohag, South-Valley University. \\ Email: $\underline{\text { mohmed2011eg@yahoo.coom }}$
}

\begin{tabular}{|c|c|}
\hline & ABSTRACT \\
\hline Received at: $24 / 3 / 2014$ & $\begin{array}{l}\text { The present study was designed to investigate the occurrence of Listeria spp. in } \\
\text { two of economically important freshwater fish species namely Oreochromis } \\
\text { niloticus (tilapia) and Clarias gariepinus which were collected from commercial } \\
\text { fish markets in Assiut, also to explore the efficiency of five ice formulations : tab } \\
\text { water ice (control), three ices sanitized using trisodium phosphate (TSP) } 2.5 \%, 5 \% \\
\text { and } 10 \% \text { in addition to an ice sanitized using sodium acetate (SA) } 2.5 \% \text { against } \\
\text { Listeria monocytogenses (LM) artificially loaded on Tilapia fish at level of } \\
\text { (5.5log10 CFU/g) and the effect of formulated ices on ice stability, sensory quality } \\
\left.\text { and pH of fish during storage at room temperature ( } 25{ }^{\circ} \mathrm{C}\right) \text {. The microbiological } \\
\text { analysis of sampled fish revealed that sampled fish represents health hazard to } \\
\text { consumer and contact surfaces. } O \text {. niloticus were more contaminated with Listeria } \\
\text { spp. compared with C.gariepinus samples (16\%and } 4 \% \text {, respectively). The } \\
\text { contamination with } L M \text { in both fish species was parallel ( } 4 \% \text { ) while Listeria } \\
\text { innocua was present in } O \text {. niloticus only ( } 12 \% \text { ). Storage of Tilapia loaded with } \\
\text { LM (5.5 log } 10 \mathrm{CFU} / \mathrm{g} \text { ) on formulated crushed ices separately for } 4 \mathrm{~h} \text { revealed that } \\
\text { both (SA) } 2.5 \% \text { and (TSP) } 10 \% \text { ices had the efficacy (P }<0.05) \text { of reduction of } L M \\
\text { on fish and in water from melted ice when compared with the control thus } \\
\text { improves the safety and reduces the potential for cross contamination. Formulated } \\
\text { ices were more stable (slow melting rate) when compared with the control. } \\
\text { Storage of fish on formulated ices for } 4 \mathrm{~h} \text { was not associated with any defects in } \\
\text { sensory parameters (P>0.05). A desirable lowering of pH values of stored fish was } \\
\text { noticed by application of (SA) } 2.5 \% \text { ice while (TSP) } 10 \% \text { ice resulted in a } \\
\text { significant rise (P<0.05) of pH at the end of storage period. Despite this study } \\
\text { demonstrates the effectiveness of (SA) } 2.5 \% \text { ice or (TSP) } 10 \% \text { ice application to } \\
\text { control the growth of } L M \text { to enhance the microbiological safety of raw fish, (SA) } \\
2.5 \% \text { ice has the advantages of its organic origin and its desirable lowering pH of } \\
\text { stored fish. The public health importance of the organism was discussed and the } \\
\text { suggestive measures for control were outlined. }\end{array}$ \\
\hline
\end{tabular}

Key words: Listeria spp., Freshwater fish, O.niloticus, Trisodium phosphate, Sodium acetate, Sensory pH.

\section{INTRODUCTION}

Fish is an excellent protein source (Jannat et al., 2010) and provides many health benefits. One such benefit is its high level of omega 3 (n-3) fatty acids, which are known to reduce cholesterol level and the incidence of stroke, heart disease and preterm delivery, Willett (2005). Also fish is one of the most highly perishable food products, Ashie and Simpson (1996).

Normally fish muscle is sterile as its immune system prevents bacteria to proliferate easily whereas after death the fish's immune system collapses allowing easily penetration of microorganisms into the flesh, Huss (1995). This penetration increase in case of fish caught from polluted area where there are high densities of bacteria, Howgate (1985). Microbial contamination can reduce the quality of fresh fish, cause economic loss and health hazards, Gram and Huss (1996).

Listeria species could be isolated from a wide range of fishery products, including freshwater and seawater fish as well as frozen and processed fish (Farber and Peterkin 1991, Gudbjornsdottir et al., 2004 and Alves et al., 2005). One particular Listeria species (Listeria monocytogenes) has been recognized as a food borne pathogen since 1981. The bacterium is ubiquitous, Gram positive, facultative anaerobic, non-spore-forming, rod-shaped (Jacquet et al., 1992 and Jay 2000) and can grow over the temperature 
range of about $1{ }^{\circ} \mathrm{C}$ to $45^{\circ} \mathrm{C}$ and $\mathrm{pH}$ range 4.1 to around 9.6. It may be expected to survive in foods for long periods of time, Ryser et al. (1985).

Contamination of fish by L.monocytogenes ( $L M)$ may take place during harvest, processing and distribution owing to improper handling and storage of fish, Kim et al. (1999). The ingestion of $L M$ in food can pose a significant health risk with reported mortality rate. Most healthy humans are not significantly affected by the intake of small numbers of $L M$ in foods. However, elderly people, pregnant women and unborn infants are the risk groups that are affected by the pathogen, FAO (1999). In human. The pathogen causes listeriosis which may range from mild to severe sickness, Adzitey and Huda (2010). The severe form of human Listeriosis is present as meningoenceophalitis followed by septic infections, Demetrios et al. (1996). Although an average of five to nine exposures to $L M$ occur per person per year, Grif et al. (2003) listeriosis is a rather rare disease, Gerner-Smidt et al. (2005) but it is associated with a mortality rate of approximately $20 \%$ to $40 \%$, Farber and Peterkin (1991), De Valk et al. (2005).

It has been reported that contamination of aquatic products with $L M$ cannot be avoided totally, hence in order to inhibit the growth and development of this pathogen in the products and to ensure safety, antimicrobial additives are needed Nykanen et al. (2000). Antimicrobial activity of any preservative depends on its hydrophilic and hydrophobic properties i.e. solubility in water and fat, distribution in the model system, fat content $\mathrm{pH}$ and temperature, Glass and Doyle (1989). The antimicrobial additives must function the suppression of bacterial growth during storage with minor effects on the quality of the products, Zhu et al. (2005).

Trisodium phosphate (TSP) is generally recognized as safe by the US Food and Drug Administration and has been approved by the US Department of Agriculture-Food Safety and Inspection Service (USDA-FSIS) at levels of $8-12 \%$ as an antimicrobial agent. Trisodium phosphate has been evaluated by several investigators for its efficacy against pathogens and has been used as an effective compound in controlling the growth of Gram -negative pathogens, Ahmed and Abd El-Atti, (2012). Also, the efficacy of sodium acetate (SA) against $L M$ has been investigated, Ghomi et al. (2011).

Research works have raised concerns about using solutions of TSP (Chang et al., 1995; Kim and Marshall, 2002) or SA (Sallam, 2007a and Sallam, $2007 b$ ) to reduce the load of $L M$ on fish. There is scarce in research papers concerning the use of TSP or SA to sanitize ice used in fish storage.

In the retail markets, fish is regularly displayed on ice to prevent spoilage and growth of pathogens. However if ice is made with sanitized water is used to store fish, it has potential to be bactericidal to the organisms, Felicano et al. (2010). Sanitized ice prepared with (TSP) or (SA) could help in achieving the goal. The aim of this study is to document the existence of listeria spp. in two economically, important freshwater fish species in Assiut markets (O. niloticus and Clarias gariepinus). A further goal is to evaluate the effectiveness of ices sanitized using TSP or SA in reducing populations of $L M$ (on fish and in water from melted ice), their effect on the sensory quality and $\mathrm{pH}$ of stored fish as well as stability of ice.

\section{MATERIALS and METHODS}

\section{1- Microbiological analysis of fish samples}

Fifty samples of freshwater fish namely Oreochromis niloticus and Clarias gariepinus (25 each) were collected from fish markets with different sanitation levels in Assiut city. All the collected samples were transferred to the laboratory in an ice box without delay where they were prepared and examined.

\section{Sampling}

Samples were taken from the left hand side of each fish in the anterior dorsal region. 25 gram muscle and its covering skin, was aseptically transferred to sterile stomacher bag. (Scott et al., 1992):

Isolation and identification of Listeria spp.: Tassou et al. (2004).

Two hundred and twenty five $\mathrm{mL}$ of sterile Listeria Selective Enrichment broth with antibioitic supplement (Difico Laboratories) was aseptically added to $25 \mathrm{~g}$ prepared sample and pummeled in a stomacher (Seward BA7021, England) then transferred to sterile flask and incubated at $30^{\circ} \mathrm{C}$ for $48 \mathrm{~h}$. After incubation the a loobfull of each broth was cultured onto Palcam Agar plates with antibioitic supplement (Difico Laboratories). After $48 \mathrm{~h}$ of incubation at $35^{\circ} \mathrm{C}$ the colonies morphologically suspected to be Listeria (black colonies with black sunken) were sub- cultured onto Tryptic Soy agar supplemented with $0.6 \%$ of yeast extract, incubated at $37{ }^{\circ} \mathrm{C}$ for $24 \mathrm{~h}$ and subjected to confirmatory tests.

All isolates were subjected to Gram's stain, motility and standard biochemical tests including, catalase, acid production from glucose, manitol, rhamnose, zylose, $\alpha$-methyl-Dmanoside, nitrate reduction, methyl red /Voges-Proskauer, B-hemolytic activity, and CAMP test, (Aygun and Pehlivanlar 2006).

\section{2- Studying effect of ices formulated using TSP or SA on ice stability, L. monocytogenes load, sensory quality and pH of fish:}

Preparation of ices: Feliciano et al. (2010).

Three concentrations, $2.5 \%, 5 \%$ and $10 \%(\mathrm{w} / \mathrm{v})$ of TSP and one concentration $(2.5 \%)$ of SA were 
prepared by reconstitution of target chemical in tab water. After stirring, the solutions were transferred to separate domestic ice cube trays and stored at $-20^{\circ} \mathrm{C}$ for a week. Ices were weight into $700 \mathrm{~g}$ batches in polyethylene bags and stored at $-20{ }^{\circ} \mathrm{C}$ until used. Tab water ice cubes was also made as a control and stored under the same conditions.

\section{Ice stability:}

For each of ice formulations, the speed of melting was determined by placing the ice cubes (of the same dimensions) in a tray that was left uncovered at room temperature $\left(25^{\circ} \mathrm{C}\right)$. At $30 \mathrm{~min}$ intervals the volume of water from melting ice was measured until the ice completely melted, Feliciano et al. (2010). All ices were tested at the same time and the test was repeated 3 times.

Preparation of bacterial inoculum: Ahmed and Abd El-Atti (2010).

One strain of L. monocytogenes ( $L M$ ) previously isolated from the examined fish samples was used. The strain was maintained on $10 \mathrm{~mL}$ Tryptic Soya agar supplemented with yeast extract (Biolife). Tryptic soya broths (Difico Laboratories) were inoculated and incubated at $30^{\circ} \mathrm{C}$ for $24 \mathrm{~h}$ to achieve viable cell populations approximately of $10^{9}$ cells/mL. Following incubation $L M$ pool was prepared by diluting $10 \mathrm{~mL}$ of the suspension with $90 \mathrm{~mL}$ of sterile peptone water to yield a final inoculum approximately $10^{8}$ cells $/ \mathrm{mL}$.

\section{Fish used in the experiment:}

Freshly caught $O$. niloticus (about $150 \mathrm{~g}$ each) were used. On arrival at the laboratory fish were gutted, washed with tab water, divided into two groups (GA $=20$ fish and $\mathrm{GB}=80$ fish) and stored in the refrigerator until used (within $30 \mathrm{~min}$ ).

\section{Loading L. monocytogenes to fish:}

The first group of fish (GA) was dipped for 60s in the $L M$ pool $\left(10^{8}\right.$ cells $\left./ \mathrm{mL}\right)$. After dipping, fish left to drain for $10 \mathrm{~min}$ in sterile tray fixed in an insulated cabinet and immediately used in the experiment.

Effect of ice formulation on $L$. monocytogenes load in fish and in water from melted ice:

Five ice treatments were used for this experiment. Tab water ice (control), three concentrations $(2.5 \%$, $5 \%$ and $10 \%$ ) TSP ices and $2.5 \%$ SA ice. Four fish were stored in each respective ice in a perforated sterile tray stand on sterile tray for collecting melted water. The fish were placed between two layers of crushed ice and left uncovered at $25{ }^{\circ} \mathrm{C}$ (ice: fish=1:1w/w and still constant until end of the experiment).

For each treatment a fish was sampled every hour and its load of $L M$ was tested. Where the fish was grinded in a sterile mortar and a 25 gram portion was a aseptically sampled to sterile stomacher bag containing $225 \mathrm{~mL}$ of 0.1 peptone water and pummeled for $1 \mathrm{~min}$ in a stomacher. Decimal dilutions were prepared and $L M$ count was done following the technique recommended by Tassou et al. (2004). The counts were transferred to $\log 10$ $\mathrm{CFU} / \mathrm{g}$. At the end of storage period (4h), melted water from each treatment was randomly sampled and its $L M$ load was determined.

\section{Effect of ice formulation on sensory quality and pH of fish:}

The $2^{\text {nd }}$ group of fish was subdivided into 5 subgroups (16 fish each). Each subgroup was stored between two layers of corresponding crushed ice treatment at $25^{\circ} \mathrm{C}$. For each treatment, four fish were sampled every hour ( 3 fish to be cooked for sensory evaluation and one for $\mathrm{pH}$ evaluation).

\section{Effect of ice formulation on the sensory quality of cooked fish:}

Treated fish were cooked separately for $15 \mathrm{~min}$ to an internal temperature of $75^{\circ} \mathrm{C}$ in a preheated conventional microwave oven adjusted to $180^{\circ} \mathrm{C}$. One representative fish sample of the different treatments was individually presented in covered small porcelain dishes to each panelist. Panelists were asked to evaluate the overall acceptability with regard to appearance, odor intensity, flavor and aftertaste, tenderness, juiciness, off-odor and off-flavor according the score recommended by Sallam (2007b). Samples receiving overall scores of more than 4 were considered acceptable, while a score between 3 and 4 was considered the borderline of acceptability.

\section{pH measurement:}

Ten grams of each ice treated samples was srperately blended with $20 \mathrm{ml}$ distilled water in a blender for 30 $\mathrm{s}$ and the $\mathrm{pH}$ of fish homogenate was measured by a digital pH-meter (Gallenhamp No.101284) standardized at pH 4 and 7, Sllam, (2007 b).

All experiments were repeated 3 times and the packaged SPSS program for windows version 12.0.1 was used for statistical analysis according to SPSS (2007). Data were expressed as mean \pm standard error (SE). Differences between groups were determined by means of a Student " $t$ "-test. Significance level was set at $P<0.05$. 
Assiut Vet. Med. J. Vol. 60 No. 141 April 2014

\section{RESULTS}

Table 1: Incidence of Listeria spp. in examined fish samples.

\begin{tabular}{|c|c|c|c|c|c|c|c|}
\hline \multirow[t]{2}{*}{ Fish spp. } & \multirow{2}{*}{$\begin{array}{c}\text { No. of } \\
\text { examined } \\
\text { samples }\end{array}$} & \multicolumn{2}{|c|}{$\begin{array}{l}\text { No .of +ve } \\
\text { Listeria.spp. }\end{array}$} & \multicolumn{2}{|c|}{$\begin{array}{l}\text { No. of +ve } L . \\
\text { monocytogenes }\end{array}$} & \multicolumn{2}{|c|}{$\begin{array}{l}\text { No. of+ve } \\
\text { L.innocua }\end{array}$} \\
\hline & & No & $\%$ & No & $\%$ & No & $\%$ \\
\hline O. niloticus & 25 & 4 & 16 & 1 & 4 & 3 & 12 \\
\hline C.gariepinus & 25 & 1 & 4 & 1 & 4 & $\mathbf{0}$ & $\mathbf{0}$ \\
\hline Total & 50 & 5 & 10 & 2 & 4 & 3 & 6 \\
\hline
\end{tabular}
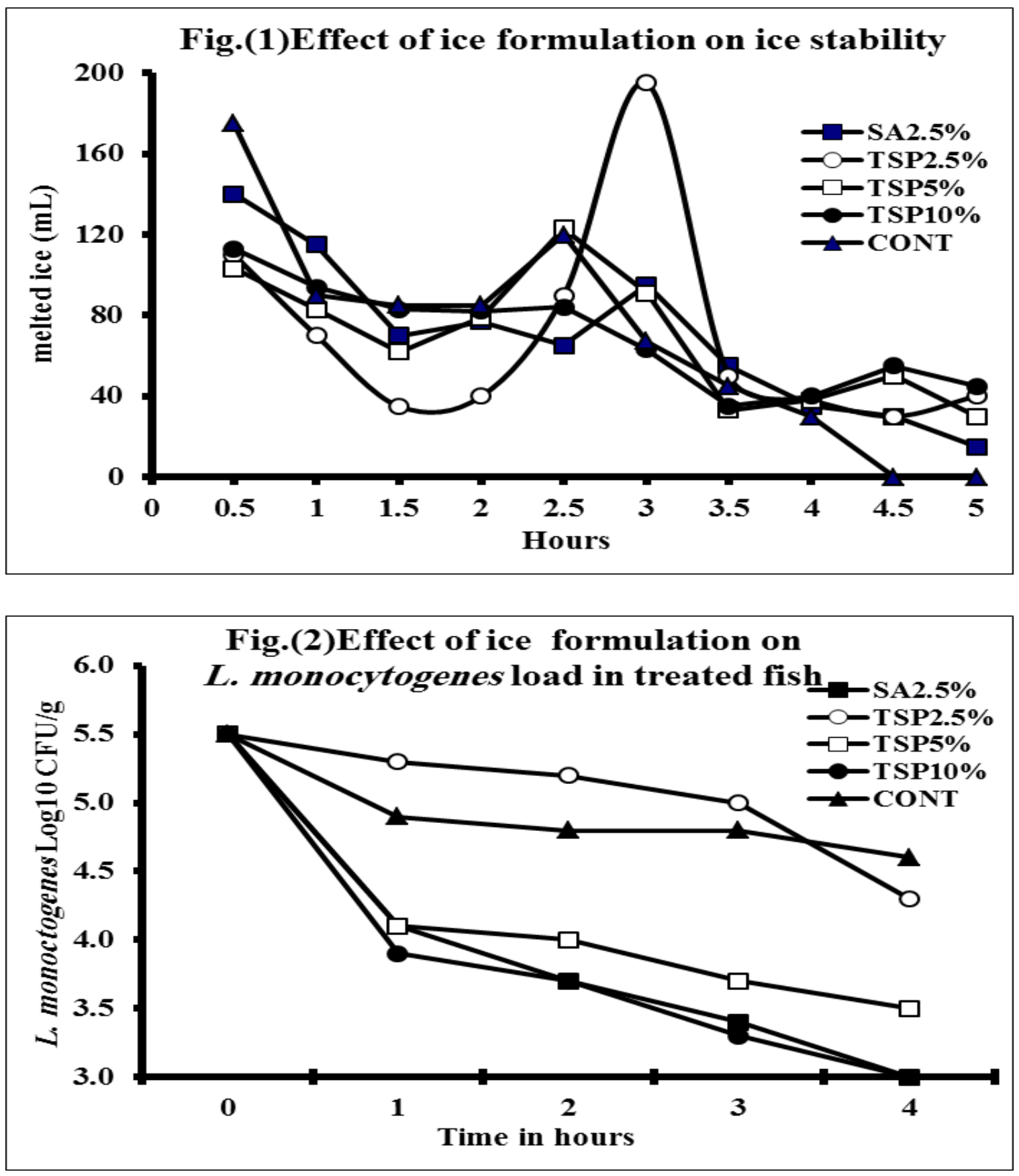


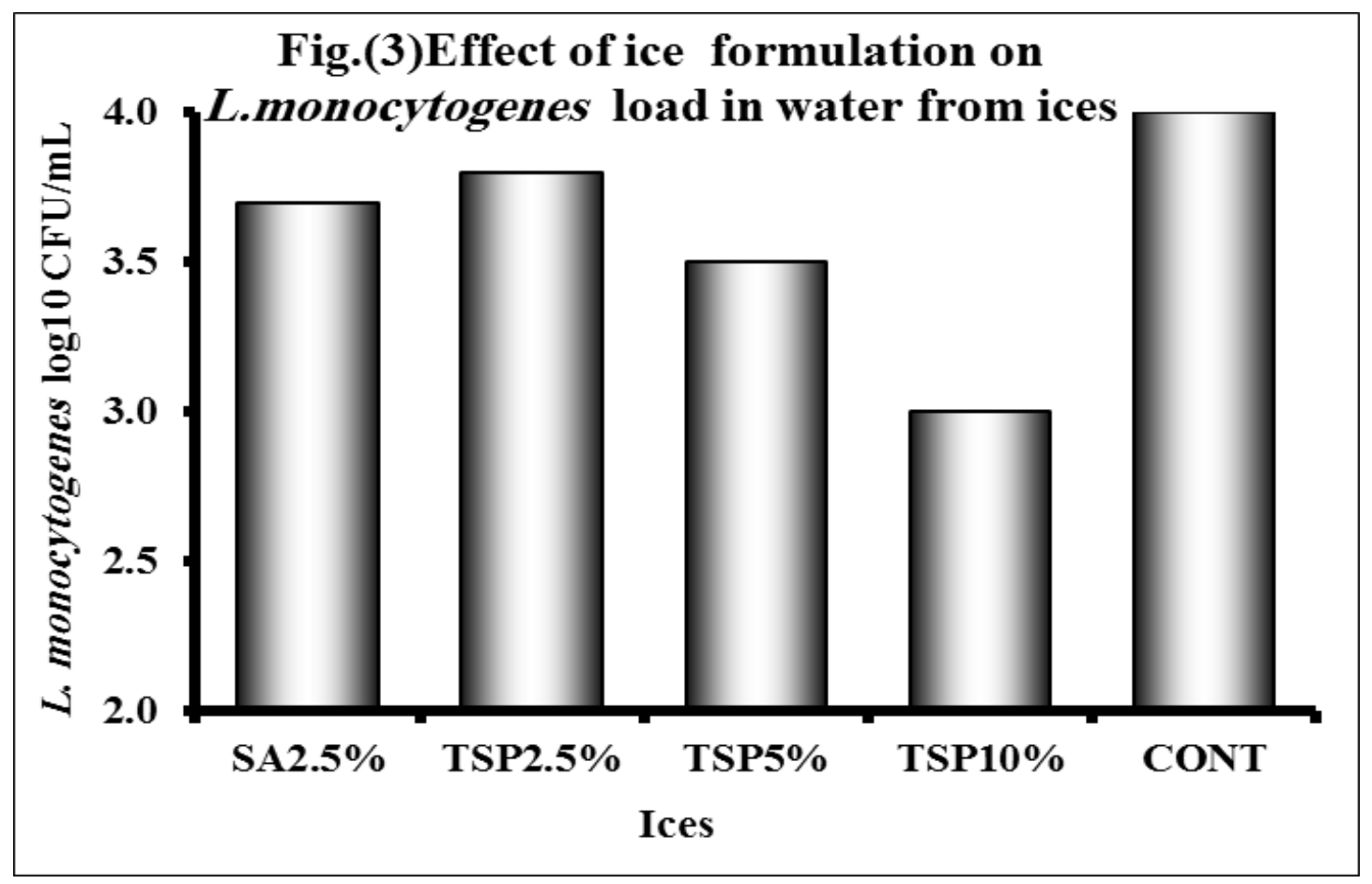

Table 2: Effect of ice formulation on the sensory quality of stored fish

\begin{tabular}{|c|c|c|c|c|c|c|c|}
\hline \multirow{2}{*}{$\begin{array}{c}\text { Duration } \\
\text { of } \\
\text { storage }\end{array}$} & \multirow[b]{2}{*}{ ices } & \multicolumn{6}{|c|}{ Mean scores } \\
\hline & & $\begin{array}{c}\text { Odor \& } \\
\text { Flav. Int. }\end{array}$ & Juiciness & Tenderness & Appearance & $\begin{array}{c}\text { Off } \\
\text { Odor \& } \\
\text { flav. }\end{array}$ & Overall score \\
\hline \multirow{5}{*}{ 1h } & SA $2.5 \%$ & 7.7 & 5.7 & 6.0 & 6.7 & 6.0 & 6.4 \\
\hline & TSP $2.5 \%$ & 7.3 & 5.7 & 5.7 & 6.7 & 5.7 & 6.2 \\
\hline & TSP 5\% & 7.7 & 5.6 & 6.0 & 7.0 & 6.0 & 6.5 \\
\hline & TSP $10 \%$ & 7.7 & 7.0 & 6.0 & 7.7 & 5.7 & 6.8 \\
\hline & Cont. & 8.0 & 7.0 & 6.0 & 8.0 & 6.0 & 7.0 \\
\hline \multirow{5}{*}{$2 \mathrm{~h}$} & SA $2.5 \%$ & 5.7 & 6.0 & 6.7 & 6.3 & 6.0 & 6.1 \\
\hline & TSP $2.5 \%$ & 6.7 & 5.7 & 7.0 & 6.0 & 6.0 & 6.3 \\
\hline & TSP 5\% & 6.7 & 5.7 & 7.0 & 6.0 & 6.0 & 6.3 \\
\hline & TSP $10 \%$ & 6.7 & 7.0 & 6.7 & 6.3 & 6.0 & 6.5 \\
\hline & Cont. & 6.3 & 6.7 & 6.3 & 6.3 & 6.0 & 6.3 \\
\hline \multirow{5}{*}{$3 \mathrm{~h}$} & SA $2.5 \%$ & 6.7 & 6.7 & 6.7 & 6.3 & 6.0 & 6.5 \\
\hline & TSP $2.5 \%$ & 6.7 & 6.3 & 6.7 & 6.3 & 6.0 & 6.4 \\
\hline & TSP 5\% & 6.3 & 6.7 & 6.7 & 6.3 & 6.0 & 6.4 \\
\hline & TSP $10 \%$ & 6.7 & 6.0 & 7.0 & 6.0 & 6.0 & 6.3 \\
\hline & Cont. & 7.3 & 7.3 & 7.6 & 6.6 & 6.3 & 7.0 \\
\hline \multirow{5}{*}{$4 h$} & SA $2.5 \%$ & 6.7 & 6.0 & 6.7 & 6.3 & 6.0 & 6.3 \\
\hline & TSP $2.5 \%$ & 6.3 & 6.3 & 6.3 & 6.3 & 6.0 & 6.2 \\
\hline & TSP 5\% & 6.3 & 6.7 & 6.3 & 6.7 & 6.0 & 6.4 \\
\hline & TSP $10 \%$ & 6.7 & 6.7 & 6.7 & 6.7 & 6.0 & 6.6 \\
\hline & Cont. & 7.3 & 7.3 & 7.3 & 6.7 & 6.0 & 6.9 \\
\hline
\end{tabular}


Table 3: Effect of ice formulation on the $\mathrm{pH}$ of stored fish

\begin{tabular}{|c|c|c|c|c|c|c|}
\hline \multirow[b]{2}{*}{ Ices } & \multirow[b]{2}{*}{ Initial pH } & \multicolumn{5}{|c|}{ Duration of storage } \\
\hline & & $\begin{array}{c}\text { pH } \\
\text { values }\end{array}$ & $1 \mathrm{~h}$ & $2 \mathrm{~h}$ & 3h & $4 \mathrm{~h}$ \\
\hline \multirow[t]{2}{*}{ SA $2.5 \%$} & \multirow{2}{*}{6.03} & mean & 5.7 & 5.9 & 6.4 & 6.1 \\
\hline & & P-value & $0.002 *$ & 0.004* & $0.04 *$ & 0.001* \\
\hline \multirow[t]{2}{*}{ TSP2.5\% } & \multirow{2}{*}{6.03} & mean & 6.2 & 6.1 & 6.7 & 6.1 \\
\hline & & P-value & 0.288 & $0.021 *$ & 0.295 & 0.001* \\
\hline \multirow[t]{2}{*}{ TSP 5\% } & \multirow{2}{*}{6.03} & mean & 5.9 & 6.4 & 6.2 & 6.5 \\
\hline & & P-value & 0.009* & 1.000 & $0.009 *$ & $0.021 *$ \\
\hline \multirow{2}{*}{ TSP $10 \%$} & \multirow{2}{*}{6.03} & mean & 6.2 & 6.7 & 6.6 & 7.1 \\
\hline & & P-value & 0.288 & 0.021* & 0.308 & $0.021 *$ \\
\hline \multirow{2}{*}{ Cont. } & \multirow{2}{*}{6.03} & mean & 6.3 & 6.4 & 6.8 & 6.8 \\
\hline & & P-value & - & - & - & - \\
\hline
\end{tabular}

\section{DISCUSSION}

From the summarized results given in Table (1) it is evident that $10 \%$ of examined fish samples contained Listeria spp. (5 out of 50 samples of O. niloticus and C. gariepinus fish). The percentages of Listeria sp. in each type of examined fish was 16 and $4 \%$ respectively, where 4 and $6 \%$ of analyzed fish contained LM and L. Innocua, respectively. $L M$ was found in a percentage of $4 \%$ in each of $O$. niloticus and $C$. gariepinus. While L.innocua could be detected in $12 \%$ of $O$. niloticus but failed to be recovered from C.garepinus.

The percentage of Listeria spp.in examined fish samples in our study is higher than that recorded by Rodas (2006) and Nikolaos (2007) where their findings were $(4.5 \%)$ and $(4.2 \%)$ respectively. Our records was lower than that reported by Joanne et al. (2004) Panda and Garg (2003) Jallewer et al. (2007), Hussein et al. (2011) Siavash et al. (2011) and Mohamed (2012), where their findings were $(23.3 \%)$, (20\%), (17.1\%) (18\%), (26.7\%), (16.7\%), respectively. Some authors confirmed our results, they recorded nearly similar percentage of Listeria spp. as Adesiyum (1993) Modaresi et al. (2011) and Shole et al. (2013), where they recorded the presence of listeria spp. in $14.8 \%, 12.4 \%$ and $10.5 \%$ of examined raw fish samples, respectively.

The findings outlined in the same Table declared that the incidence of $L M$ in raw fish samples was (4\%). This trend was higher than that obtained by Panda and Garg (2003), Nikolaos (2007) and Rahimi et al. (2012) which were $(1.9 \%, 1.7 \%$ and $0.8 \%)$, respectvely. Our findings was lower than that reported by Rodas (2006), Jallewer et al. (2007), Modaresi et al. (2011), Mohamed (2012) and Shole et al. (2013), where their records were (22.7\%), $(\% 10),(67 \%),(21 \%)$ and $(7.3 \%)$, respectively. On the other hand, the incidence of this organism was nearly agreed with that results obtained by Siavash et al. (2011) Joanne et al. (2004) and Hussein et al. (2011) who recorded $4 \%, 3.8 \%$ and $3.2 \%$ respectively. Other studies have found that the prevalence of $L M$ in raw fish is quite low, ranging from (0 to 1\%) Autio et al. (1999) and Johansson et al. (1999). Jemmi and Keusch (1994) and Hartemink and Georgesson (1991) stated that in Iceland $56 \%$ of fresh fish on sale were contaminated with $L M$ and other listeria spp. However many investigators as karunasagar et al. (1992), Kamat and Nair (1994) and Papadopoulos et al. (2010) could not isolated LM from any of fresh water fish samples. Many results suggest that the absence of $L M$ in tropical fish is due to using inadequate methodology. Reliable and accurate isolation and detection techniques are important in the surveillance of $L M$, Shole (2013).

L. innocua as presented in Table (1) was recovered from the fish in a percentage of $6 \%$ which was higher than that reported by Shole et al. (2013) who recorded $0.9 \%$ while Panda and Garg (2003) and Siavash et al. (2011) recorded higher percentages of L. innocua than in our study $(17 \%$ and $11 \%)$, respectively. On the other side the percentage of $L$. innocua was somewhat agreed with the result detected by Hussein et al. (2011) and Rahimi et al. (2013) which were (8.4\% and $5.7 \%$, respectively). Our study showed that L.innocua was predominant among Listeria spp. and this agreed with the result obtained by Adzitey and Huda (2010) Since both $L M$ and L. innocua share the ecological niches, and the isolation of both bacteria is not surprising. where isolation of L.innocua in fishery products is considered as an indicator of possible contamination with $L M$.

The differences in prevalence of Listeria spp. may be due to the facts that: type of samples, methods of sampling, isolation techniques, geographical area and even climate of area which samples were collected, Hassan and Shole et al. (2013). In addition, contact with intestinal contents is risk factor for prevalence of 
Listeria spp. in seafood samples, Ertas and Seker (2005).

Effect of ice formulation on ice stability, $L$. monocytogenes load (in fish and melted water), sensory quality and pH of fish:

\section{Ice stability:}

Results from the ice stability in showed that, tap water ice appeared to melt faster than other ices (Figure 1). For example, after $60 \mathrm{~min}$ storage time, the volume of water collected from tap water ice was $265 \mathrm{~mL}$ whereas 255, 180, 186 and $207 \mathrm{~mL}$ were collected from (SA) $2.5 \%$ (TSP) $2.5 \%$, (TSP) $5 \%$ and (TSP) $10 \%$ ices, respectively. However, for most storage times after that, the volume collected from all treatments appeared to be relatively similar, except around the 3-2.5 h storage period. In general, formulated ices are more stable (700 $\mathrm{g}$ ice melted completely in $5 \mathrm{~h}$ versus $4 \mathrm{~h}$ to tab water ice).

\section{Efficacy of ice formulations in reduction of Listeria monocytogenes load in fish and in water from melted ice:}

To evaluate the effectiveness of antimicrobial ices, viable $L M$ on agar surface were enumerated following treatments. As shown in Figure 2, the initial $L M$ count was $5.5 \log 10 \mathrm{CUF} / \mathrm{g}$. The initial count was reduced by $1.4,0.2,1.4,1.6$ and $0.6 \log 10 \mathrm{CFU} / \mathrm{g}$ for (SA) $2.5 \%$, (TSP) $2.5 \%$, (TSP) $5 \%$, (TSP) $10 \%$ and tape water ices at one hour sampling period, respectively. At two hours storage, the treatments were effective in achieving desired $\log 10$-unit reduction except TSP $2.5 \%$ and tap water ices. A reduction level of $\log _{10^{-}}$ unit using (TSP) $2.5 \%$ ice was achieved after $4 \mathrm{~h}$ of storage. Whereas (SA) $2.5 \%$ ice was more effective at same concentration and storage time.

The rate of reduction was dependent on the concentration for TSP ices. For example, reductions in $L M$ cells were 1.2,2.0 and 2.5 $\log 10 \mathrm{CFU} / \mathrm{g}$ for (TSP) $2.5 \%$, TSP 5\% and TSP $10 \%$ ices at the 4 th sampling period, respectively. The results in Figure 2 also shows that (SA) $2.5 \%$ and TSP $10 \%$ ices were the most effective compared with the control (1.6 $\log 10 \mathrm{CFU} / \mathrm{g}$ additional reduction to control) followed by (TSP) 5\% (0.6 $\log 10 \mathrm{CFU} / \mathrm{g}$ reduction additional to control) at the $4^{\text {th }}$ hour of the storage period. Statistically, there were significant difference (data not shown) in the reductions between the ice treatments prepared from tap water and ices formulated using (SA) $2.5 \%$ or (TSP) $10 \%$. Sodium acetate $2.5 \%$ or (TSP) $10 \%$ ices was efficient in reduction of LM in treated fish compared with control ice $(\mathrm{P}<0.05)$.

Figure 3 shows the amount of $L M$ cells recovered in the waters collected from the ice treatments after $4 \mathrm{~h}$ storage. The mean $L M$ viable cells recovered were 3.7,3.8,3.5,3.0 and 4.0 $\log 10 \mathrm{CFU} / \mathrm{ml}$ of melted ice for (SA) $2.5 \%$, (TSP) $2.5 \%$, (TSP) $5 \%$, (TSP) $10 \%$ and tap water ices, respectively. Statistically, (TSP)
$10 \%$ ice was the most efficient in reduction of $L M$ population in the water from melted ice $(\mathrm{P}<0.001)$ compared with tab water ice while only a significant difference $(\mathrm{P}<0.05)$ for other formulated ices compared with tab water ice.

This study, confirmed that formulated ices especially (SA) $2.5 \%$ or (TSP) $10 \%$ ice can help to overcome the $L M$ burden in the water when it used to store the fish. This thus reduced the potential for crosscontamination to contact surfaces and even to the environment of the market.

To evaluate sanitizers some factors should be taken into consideration before making any assumption. For example, animal products (fish and meat) are foods rich in proteins and/or lipids. It has been reported that even low amounts of proteins or fats are capable for reducing the antimicrobial efficacy of sanitizers) Vandekindern et al. (2009). In addition, it is documented that temperature also influences the efficacy of the sanitizer where Venkitanarayana et al. (1999) found that $L M$ was more rapidly inactivated by sanitizers at $35{ }^{\circ} \mathrm{C}$ and $45^{\circ} \mathrm{C}$ than at $4{ }^{\circ} \mathrm{C}$ or 23 ${ }^{\circ} \mathrm{C}$. $L M$ is also tolerant and survives in extreme conditions like a wide $\mathrm{PH}$ range (4.1-9.6), Adzitey and Huda (2010). Regarding TSP, Taormina and Beuchat (2013) revealed that $L M$ survived at least 6 days when they were suspended in TSP at pH 9.0 and stored at $4{ }^{\circ} \mathrm{C}$ for 21 days. Capita et al. (2001) found that the rate of $L M$ reduction was increased by increasing TSP concentration. The behavior of $L M$ was significantly influenced by the origin of the strain and salt concentration in their experiment .

There is lake of researched papers about using of SA or TSP in ice formulations but the potential of using their solutions to reduce bacterial populations in fresh fishery products was explored. Kim and Marshall (2002) recorded a reduction of 0.6 to less than 1.8 $\log 10$ CUF of $L M$ on fish skin when treated for 10 min using TSP 2-6\%. Whereas, Mu et al. (1997) mentioned that 10 or $20 \%$ solution treatments of TSP didn't significantly reduce Listeria populations in fish fillets after 6 days of storage.

Sodium acetate is widely available, economical and generally "recognized-as-safe "Sallam (2007 a). The available literatures focused on using its solutions for dipping of fish. Golden (1995) explored that Listeria inactivation was directly related to the concentration and incubation temperature and inversely related to pH. Kouassi and Shelf (1996) found that SA was effective antilisterial at concentration of $3 \%$ at $37{ }^{\circ} \mathrm{C}$. Sallam (2007 a) noticed that aqueous solution of (SA) $2.5 \%$ was efficient against proliferation of various categories of spoilage microorganisms of fish under refrigerated storage.

Effect of ice formulation on sensory quality of treated fish:

The mean values for odor and flavor intensity, juiciness, tenderness, appearance and off odor and 
flavor of cooked fish are illustrated in table (2). The analysis of these values showed non-significant difference between treated and control fish (data not shown). All treated fish were judged acceptable by the sensory panel. No off-odor or off-flavor could be detected in any of treated fish. The results regarding sensory evaluation of treated fish are in accordance with the finding of other researchers who treated fish with SA or TSP. Kilinc et al. (2009) found that dipping of fish in (TSP) $5 \%$ for $10 \mathrm{~min}$ did not affect the texture of fish fillets. Vyncke (1978) revealed that dipping of fish in a solution of sodium tripolyphosphate for $5 \mathrm{~min}$ improved the appearance of treated fish. Sodium salt of acetic acid has been used to improve sensory quality attributes and extend the shelf life of fish. Sallam (2007 b) noticed no difference in appearance, Juiciness and tenderness in fish dipped in $2.5 \%$ aqueous solution of SA compared with control. Manjua et al. (2007) found that SA treated fish (2\% Sol.) still acceptable during refrigerator storage for 15 day. Kim et al. (1995) summarized that fish fillets treated with (SA) $1 \%$ had an appearance and odor scores similar to fresh controls up to 3 days of refrigerator storage. We can summarized that treating fresh fish with the studied SA or TSP ice formulations can maintain the sensory quality of the treated fish when stored at room temperature $\left(25^{\circ} \mathrm{C}\right)$.

\section{Effect of ice formulation on $\mathrm{pH}$ of treated fish :}

Values regarding the effect of ices on the $\mathrm{pH}$ of fish muscles during storage at room temperature $\left(25^{\circ} \mathrm{C}\right)$ are shown in table3. The initial $\mathrm{pH}$ value of fresh control fish (6.03) was significantly higher $(\mathrm{P}<05.0)$ than those treated with (SA) $2.5 \%$ or (TSP) $5 \%$ ices but not tap water ice at the end of $1^{\text {st }}$ hour of storage on ice. A significant decrease in the $\mathrm{pH}$ value of fish treated with (SA) $2.5 \%$ ice compared with the control was also observed at the $2^{\text {nd }}, 3^{\text {rd }}$ and $4^{\text {th }}$ hour of storage $(\mathrm{P}<05.0)$. At the end of storage time $(4 \mathrm{~h})$ a significance reduction of $\mathrm{pH}$ was observed in samples treated with (SA) $2.5 \%$ (6.1), (TSP) $2.5 \%$ (6.1) and (TSP) 5\% (6.5) compared with the control (6.8). Trisodium phosphate $10 \%$ ice resulted in a significance $(\mathrm{p}<05.0)$ rising of $\mathrm{pH}$ of treated fish muscles at the $2^{\text {nd }}$ and $4^{\text {th }}$ sampling periods compared with the control, but still near the acceptable $\mathrm{pH}$ range of fish (6.6-6.8) recommended by Ross et al. (2000) The reductions of $\mathrm{pH}$ of fish muscles after treatment with SA in our experiment are consistent with those of Sallam (2007b) and Kim et al. (1995). In respect for TSP, Mu et al. (1997) recorded the rising in the $\mathrm{pH}$ values of fish fillets treated with TSP (10\% solution) compared with the control.

We can summarized that SA ice treated fish had a significantly $(\mathrm{p}<05.0)$ low $\mathrm{pH}$ values compared with the control along the storage period (4h). The reduction of $\mathrm{pH}$ is the main function of acetic acid and it is salts when added to foods. That reduction did not affect sensory attributes of fish as revealed in the sensory evaluation. The relative high $\mathrm{pH}$ values in fish treated with (TSP) $10 \%$ ice compared with control may due to high skin $\mathrm{pH}$ value which recorded by $\mathrm{Mu}$ et al. (1997). The relatively high $\mathrm{pH}$ value ( 0.2 more than control) did not reflected in the sensory attribute tested by panels.

\section{CONCLUSION}

Chilling to about $0{ }^{\circ} \mathrm{C}$ is the most important means of fresh marketing in Egypt. The most common chilling media is ice. The finding during this study confirmed that Bolti (O. niloticus) and $C$. gariepinus from Assiut markets were contaminated by listeria $(16 \%$ and $4 \%$, respectively). Consequently raw fish and water from melting ice in contact can become a source of cross contamination if not dealt with properly. This potential could be significantly ( $p$ $<05.0$ ) reduced by the use of (TSP) $10 \%$ or (SA) $2.5 \%$ ice. These ice formulations did not affect any of sensory quality parameters or the overall acceptability of fish compared with control $(p>05.0)$ and can be utilized as safe preservatives for fish under room temperature storage thus improving fish safety and protect public health.

\section{REFERENCES}

Adesiyum, A.A. (1993): Prevalence of Listeria spp., Campylobacter spp., Salmonella spp., Yersinia spp. and toxigenic E. coli on meat and seafood in Trinidad. Food Micribiol.10: 395-403.

Adzitey, F. and Huda, N. (2010): Listeria monocytogenes in foods. Incidences and possible control .Afri. J. of Microbial. Research 4: 2848-2852.

Ahmed, A.M. and Abd El-Atti, Nashwa, A. (2012): Existence of Listeria species in broiler carcasses with an attempt to control Listeria monocytogenes using trisodium phosphate. Afri. J. of Food Sci.4 (2), 046-051.

Alves, V.F.; De Martinis, E.C.; Destro, M.T.; Vogel, B.F. and Gram, L. (2005): Anti Listeria activity of Carnobacterium piscicola isolated from Brazilian smoked fish (surubim pseudoplatystoma spp.) and its activity against a persistent strain of Listeria monocytogenes isolated from surubim. J. Food Prot. 68: 20682077.

Ashie, I.N.A. and Simpson, B.K. (1996): Application of high hydrostatic pressure to control enzyme related fresh sea food texture deterioration. Food Research International. 29 (5-6) 569-575.

Aygun, O. and Pehlivanlar, S. (2006): Listeria spp. in the raw milk and dairy products in Antakya, Turkey, Food Control. 17: 676-679.

Autio, T.; Hielem, S.; Miettinen, M.; Sjoberg, A.M.; Aarnisalo, K. and Bjork roth, J. (1999): Sources of L. monocytogenes contamination in a cold -smoked rainbow trout processing plant detected by pulsed-field gel electrophoresis 
typing. Appl. and Environ. Microbiol. 65, 150155.

Aygun, O. and Pehlivanlar, S. (2006): Listeria spp. in the raw milk and dairy products in Antakya, Turkey. Food Control. 17: 676-679.

Ben Embarek, P.K. (1994): Presence, detection and growth of Listeria monocytogenes in seafood. A review. Int. J. Food Microbiol 23:17-34.

Capita, R.; Alonso-Calleja, M.C. and Moreno, B. (2001): Influence of strain and trisodium phosphate concentration on growth parameters of Listeria monocytogenes in vitro. Lett. Appl. Microbiol. 32(6), 428-32.

Chang, K.R.; James, H.O.; Amy, V.P.; Charles, W.H.; Marshall, H. and Douglas, L. (1995): Extending shelf life of refrigerated cat fish fillets using sodium acetate and monopotassium phosphate. J. Food Prot. 6: 597-708.

Demetrios, K.; Bori, M. and Antonios, M. (1996): Growth of Listeria monocytogenes in the whey cheeses, Myzi theria, Anthotyros, and Manouri during storage at 5,12 and $22 \mathrm{C}^{\circ}$. Food Prot. 59: 1193-1199.

De Valk, H.; Jacquet, C.; Goylet, V.; Vaillant, V.; Perra, A.; Smon, F.; Desenclos, J.C. and Martin, P. (2005): Surveillance of Listeria infections in Europe. Eurosurveillance 10:251255.

Ertas, H.B. and Seker, E. (2005): Isolation of Listeria monocytogenes from fish intestines and RAPD analysis, Turkish J. of Vet. and Animal Scie. Vol. 29: 1007-1011.

FAO (1999): Report of the FAO expert consultation on the trade impact of Listeria in fish products. FAO Fisheries Report No 64. FIIU/ESNS/R604, Amherst, MA, United States.

Farber, J.M. and Peterkin, P.I. (1991): Listeria monocytogenes, a foodborne pathogen. Microbiol. Rev. 55: 476-511.

Feliciano, L.; Lee, J.; Lopes, J. and Pascall, M.A. (2010): Efficacy of sanitized ice in reducing bacterial load on fish fillet and in the water collected from the melted ice. J. Food Sci. 75(4), 231-238.

Gerner-Smidt, P.; Ethelberg, W.; Schiellerup, P.; Christensen, J.; Engeberg, J.; Fussing, V.; Jensen, A.; Petersen, A.M. and Bruun, B.G. (2005): Invasive listeriosis in Denmark 19942003: a review of 299 cases with special emphasis on risk factors for mortality. Clinic. Microbiol. Infect, 11: 618-624.

Ghomi, M.R.; Nikoo, M.; Heshmatipour, Z.; Amir, J.A.; Ovissipour, M.; Hashemi, F.L.H.; Hasandoost, M. and Jadiddokhani, D. (2011): Effects of sodium acetate and nisin on microbial and chemical changes and fatty acid composition of grass carp Ctenopharyngodon idella during refrigeration storage. Food Saf.,Doi:10.1111/j.1745-4565.2010.00281.x.

Glass, K.A. and Doyle, M.P. (1989): Fate of Listeria in processed meat products during refrigerated storage. Appl. Environ. Microbiol. 55: 15651569.

Golden, M.H.; Buchanan, R.L. and Whiting, R.C. (1995): Effect of sodium acetate or sodium phosphate with EDTA and ascorbic acid on the inactivation of L. monocytogenes Food Safety Vol.15,1:53-56

Gram, L. and Huss, H.H. (1996): Microbiological spoilage of fish and fish products. Int. J. Food Microbiol. 33: 121-137.

Grif, K.; Patscheider, F. and Dierich, M.P. (2003): Incidence of fecal carriage of Listeria monocytogenes in three healthy volunteers: a one-year prospective stool survey. Eur. J. Clinic. Microbiol. Infect. Dis. 22: 16-20.

Gudbjornsdottir, B.; Suiko, M.L.; Gustavsson, P.; Thorkelsson, G.; Salo, S. and Sjoberg, A.M. (2004): The incidence of $L$. monocytogenes in meat, poultry and seafood plants in Nordic Countries. J. Food Microbiol. 21:217-225.

Hartemink, R. and Georgsson, F. (1991): Incidence of Listeria species in sea food and seafood salads. Int. J. of Food Microbiol. 12:189-195.

Hassan, M. and Shole, Y. (2013): Molecular characterization of Listeria monocytogenes isolated from fresh seafood samples in Iran. http://www.diagnosticpathology.org/content/8/ $1 / 149$.

Howgate, P. (1985): The self-life of fish products. J. Sci. Food Agric. 36 (2), 126-127.

Huss, H.H. (1995): Quality and quality changes in fresh fish. Food Agriculture Organization (FAO), Fisheries Technical Paper 348. Rome: FAO.

Hussein, A.; Othman, R.E.E.; Sayed, S.M.A.; Hassanein, R. and Abushahahba, F.N.M. (2011): Occurrence of Listeria monocytogenes in poultry, fish and their products as well as its public health hazard on women. Animal hygiene and sustainable livestock production. Proceedings of the XVth International Congress of the International Society for Animal Hygiene, Vienna, Austria, 3-7, Vol.2: 987-992.

Jacquet, C.; Aubert, S.; El Solh, N. and Rocourt, J. (1992): Use of rRNA gene restriction patterns for the identification of Listeria species. Systematic and Appl. Microbiol. 15: 42-46.

Jallewar, P.K.; Kalorey, D.R.; Kurkure, N.V.; Pande, V.V. and Barbuddhe, S.B. (2007): Genotypic characterization of Listeria spp. isolated from freshwater fish. Internat. J. Food Microbiol. 114: 120-123.

Jammi, T. and Keusch, A. (1994): Occurrence of $L$. monocytogenes in fresh water fish farms and 
fish smoking plants. Food Microbiol. 11:309316.

Jannat, A.H.; Shabanpoor, B.; Shabani, A. and Sadeghi, A. (2010): Effects of cooking methods on physico-chemical and nutritional properties of Persian sturgeon Acipenser persicus fillet. Int. Aquat. Res., 2: 15-23.

Jay, J.M. (2000): Modern Food Microbiology. An Aspen Publication and Aspen publishers, Inc. Gaithersburg, Maryland.

Joanne, T.; Kendra, K.N.; Ken, G.; Virginia, N.S. and Martin, W. (2004): Tracking of Listeria monocytogenes in smoked fish processing plants. J. of Food Prot. Vol.67 (2), 328-341.

Johansson, T.; Rantala, L.; PaLMu, L. and Honkanen-Huzalski, T. (1999): Occurrence and typing of L. monocytogenes strains in retail vaccum-packed fish products and in a production plant. Internat. J. Food Microbiol. 47:111-119.

Kamat, A.A. and Nair, P.M. (1994): Incidence of Listeria species in India sea foods and meat. $\mathrm{J}$. Food Safety 14: 117-130.

Karunasagar, I.; Segar, K.; Karunasagar, I. and Goebel, W. (1992): Incidence of Listeria spp. in tropical seafoods. in: Listeria. Abstract No. 155. Eleventh international Symposium on problems of Listeriosis (ISOPOL XI), May $11^{\text {th }}-14^{\text {th }}$, Copenhagen, Denmark.

Kilinc, B.; Cakli, S.; Candun, A. and Sen, B. (2009): Effects of phosphate dip treatments on chemical, microbiological, color, textural and sensory changes of Rainbow trout fillets during refrigerate storage. Aquatic Food Product Teechnology (24), 110-119.

Kim and Marshall (2002): Influence of catfish skin mucus on trisodium phosphate inactivation of attached Salmonella typhimurium,Edwardsiell a tarda, and Listeria monocytogenes. J. Food Prot. 65(7), 1146-1151.

Kim, C.R.; James, O.H; Vickery, A.P.; White, C.H. and Marshall, D.L. (1995): Sodium acetate and Bifidobacteria increase shelf life of refrigerated catfish fillet. Food Sci. 60 (1), 15-27.

Kim, J.M.; Huang, T.S.; Marshall, M.R. and Wei, C.I. (1999): Chlorine dioxide treatment of seafood to reduce bacterial loads. Food Sci. 64: 1089-1090.

Kouassi, Y. and Shelf, L.A. (1996): Metabolic activities of L. monocytogenes in the presence of sodium propionate, acetate , lactate and citrate,Appl.Bacteriol .81(2), 147-153.

Modaresi, R.; Mardani, K.; Tukmechi, A. and Ownagh, A. (2011): Prevalence of Listeria spp. in fish obtained from Urmia fish markets. African J. Microbiol. 5(30), 5398-5401.

Manjua, S.; Ravishankarb, C.N. and Lalithac, K.V. (2007): Effects of sodium acetate dip treatment and vacuum- packaging on chemical, microbiological, textural and sensory changes of (Pearlspot) Etroplus saratensis during chill storage. Food Chemistry. 102(1) 27-37.

Mohamed, G.M. (2012): Comparative study between raw and cooked fish sold in Assiut city on the incidence of some foodborne pathogens. Assiut Vet. Med., J. Vol. 58, 133: 99-108.

Mu, D.; Huang, Y.; Gates, K. and WU, W. (1997): Effectof trisodium phosphate on $L$. monocytogenes attached to Ranibow trout and shrimp during refrigerated storage. Food Safety. 17(1) 37-46.

Nikolaos, S.; Amin, A.; Konstantinon, P. and Vasikios, S. (2007): Incidence of Listeria spp in fish and environment of markets in Northern Greece. Food Control 18: 554-557.

Nykanen, A.; Weckman, K. and Lapvetalainen, A. (2000): Synergistic inhibition of listeria monocytogenes on cold-smoked Rainbow trout by nisin and sodium lactate. Internat. J. Food Microbiol. 61: 63-72.

Pand, A.K. and Garg, S.R. (2003): Prevalence of Listeria in foods of animal origin. Indian $\mathrm{J}$. Anim. Sci. 73: 967-968.

Papadopoulos,bTh.;bAbrahim, A.; Sergelidis, D.; Kirkoudis, I. and Bitchava, K. (2010): Prevalence of Listeria spp. in freshwater fish (Oncorhynchus mykiss and Carassius gibelio) and the environment of fish markets in Northern Greece. J. Hellenic Vet. Med. Soc.61(1), 15-22.

Rahimi, E.; Shakerian, A. and Raissy, M. (2012): Prevalence of Listeria species in fresh and frozen fish and shrimp in Iran," Annals of Microbiol. 62:37-40.

Rodas, O.R.; Flores, J.F.; Betancourt, J.M.; Quinones, E.I. and Vazquez, C. (2006): Occurrence and antibiotic Sensitivity of Lisreria monocytogenes strains isolation from oysters, fish,and estuarine water. Appl, Environ. Microbiol. 72(11), 7410-7412.

Ross, T.; Dalgaard, P. and Tienungoon, S. (2000): Predective modeling of the growth and survival of Listeria in fishery products. Internat. J. Food Microbiol. 62: 231-245.

Ryser, E.T.; Marth, E.H. and Doyle, M.P. (1985): Survival of Listeria monocytogenes during manufacture and storage of cottage cheese. J. Food Prot. 48: 746-750.

Sallam, K.I. (2007 a): Chemical, sensory and shelf life evaluation of sliced salmon treated with salts of organic acids. Food Chem. 101 (2), 592-600.

Sallam, K.I. (2007b): Antimicrobial and antioxidant effects of sodium acetate, sodium lactate and sodium citrate in refrigerated sliced salmon. Food Control. 18(5), 566-575.

Scott, D.; Fletcher, G.C.; Charles, J.C. and Wang, R.J. (1992): Spoilage changes in the deepwater fish Smooth oreodory during storage in 
ice. Internat. J. Food Sci. Technol. 27: 577587.

Shole, Y.; Hassan, M.M.D. and Elahe, T.B. (2013): Listeria monocytogenes serotypes in fresh fish, shrimp, crab and lobster in Isfahan and Shahrekord, Iran. Inte. J. of Advan. Biological and Biomedical Research, Volume 1, Issue 5,: 493-504.

Siavash, M.; Ali, F. and Samhra, E. (2011): Incidence of Listeria Species in farmed tropical fish in Khuzestan, Iran. World J. of Fish and Marine Scie. 3(3), 206-209.

SPSS (2007): Sample Power Statistic, SPSS, 12.01Syntax Reference Guide for SPSS Base. SPSS Inc, 233 South Wacker Drive, Chicago, IL.pp111-119.

Taormina, P.J. and Beuchat, L.R. (2003): Survival and heat resistance of Listeria monocytogenes after exposure to alkali and chlorine. Appl. Environ. Microbiol.79: 24-29.

Tassou, C.C.; Lambropoulou, K. and Nychas, G.J.E. (2004): Effect of prestorage treatment and storage condtion on the survival of Salmonella enteritidis PT4 and Listeria monocytogenes on fresh marine and freshwater aquaculture fish. Food Protect. 67(1), 193-198.

Vandekinderen, I.; Devliehgfrf, E.; Van Camp, J.; Kerhaert, B.; Cucu, T.; Ragaert, P.; De Bruyne, J. and De Meulemaer, B. (2009): Effects of food composition on the activation of foodborne microorganisms by chlorine dioxide. Internat. J. Food Microbiol. 131: 3844.

Venkitanarayanan, K.S.; Ezeike, G.O.; Hung, Y.C. and Doyle, M.P. (1999): Efficacy of electrolyzed oxdizing water for inactivation of Escherichia coli O157:H7, Salmonella enteritidis and Listeria monocytogenes .Appl. Environ. Microbiol. 65: 4276.

Vyncke, W. (1978): Infuence of sodium tripolyphosphate and citric acid on the shelf life of thornback ray (Raja clavata L.). Zlebensum Unters 28, 166(5)284-286.

Willett, W.C. (2005): Fish balancing health risks and benefits. Amer. J. Prev. Med. 29: 320-32 Zhu, M. Du. M.; Cordray, J. and Ahn, D.U. (2005): Control of Listeria monocytogenes Contamination in Ready-to-Eat Meat Products. Comprehensive Rev. Food Saf., 22: 34-42.

\section{تواجد ميكروبات الليستيريا في أسماك الماء العذب والسيطرة عليها بإستخدام التخج المطهر}

محمود عمار محمد عمار ، غاده محمد محمد ، ناهد محموب عبد العزيز

E mail: mohmed2011eg@yahoo.coom

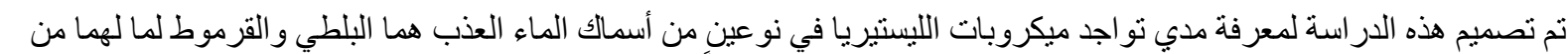

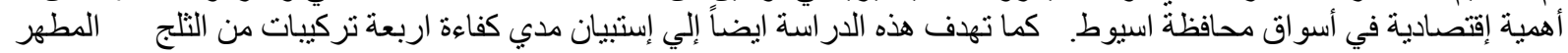

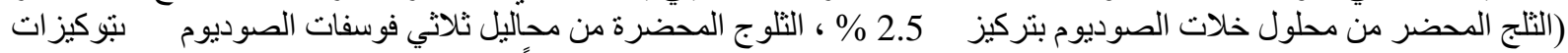

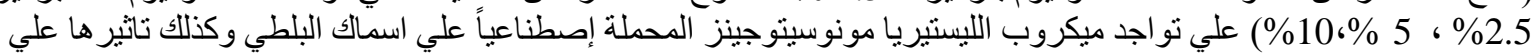

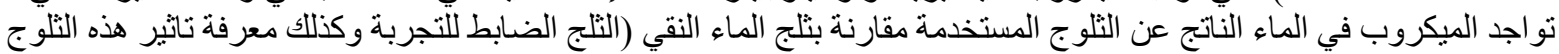

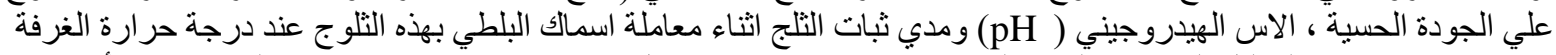

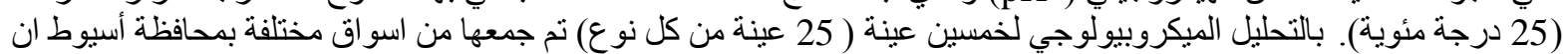

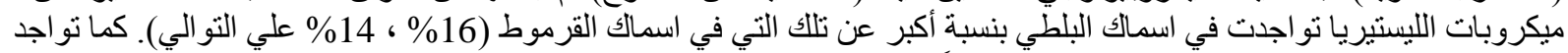

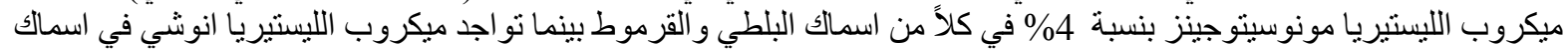

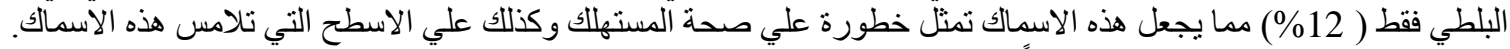

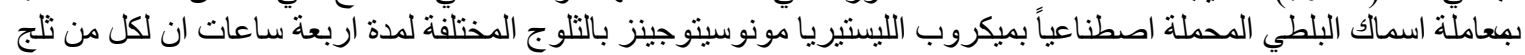

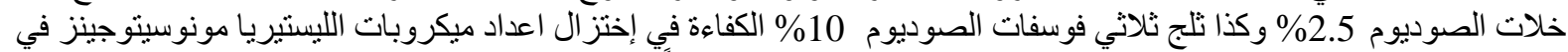

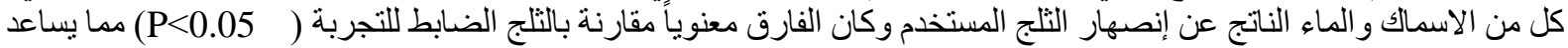

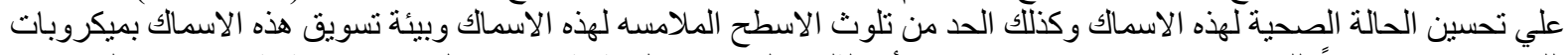

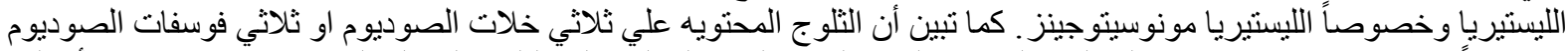

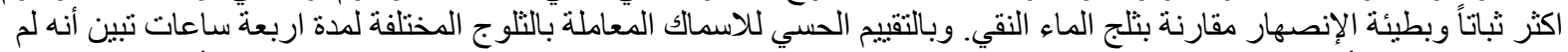

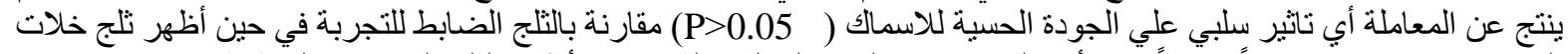

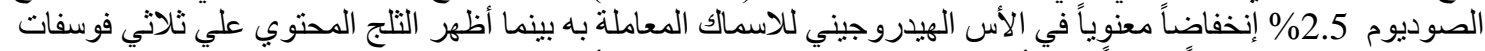

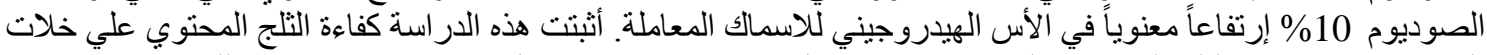

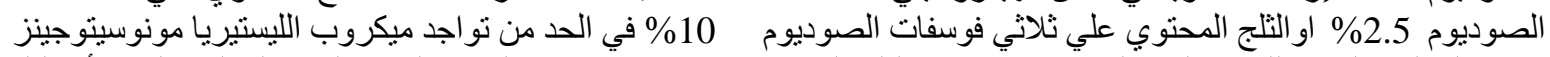

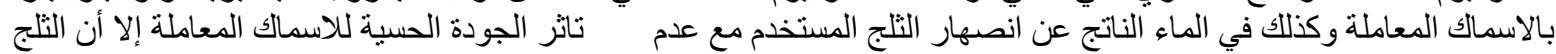

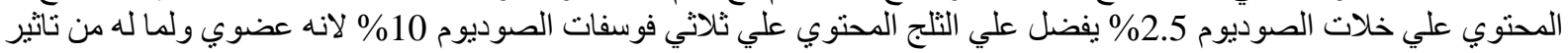

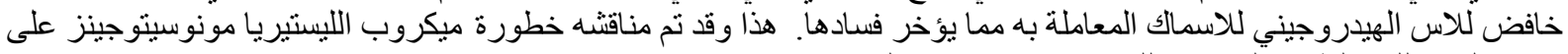
صحه المستهلك و الطرق الكقترحه للحد من تو اجدة لبلإسماك. 